\title{
IMPACT OF DIGITAL RUMOURS IN AN ACUTE EVENT (With reference to WhatsApp users)
}

\author{
R. Hepzibah Gnana Sinthiya \\ Dr. Kishore Kulothungan
}

\begin{abstract}
The world is stumbled with the acute virus called COVID-19. Besides the spread of the virus, the rumours about the virus spread faster. This study focuses on the types of rumours that arose and spread during the acute event and the impact of such rumours on the netizens and also highlights the steps taken by the government to control the rumours. Both the primary and secondary data are used. The primary data was collected from 7 groups of a Netizen WhatsApp number and various literature was studied for the secondary data. A rumour classification model has developed with the help of secondary data. The statistical tool ANOVA is used to analyze the impact of different types of rumours. This study reveals that the Occurrence of Catholicon rumours and Subject Buzz rumors are more than the other rumours. Therefore, this study concludes by stating that all the rumours have an equal impact on society since people are more concerned about their health. Suggestions and techniques were given to identify and deduct rumours for both the WhatsApp users and the Whatsapp company.
\end{abstract}

Keywords: Covid-19, Home remedies, Quarantine, Rumours, WhatsApp, Fake news, Techniques.

\section{Introduction}

According to a verse in Bible (Proverbs 26:20), the importance of words expressed during acute events spread fast due to the anxiety among people . People react differently during critical situations according to the incidents they face. Now a day's communication has become very simpler with the help of social media networks. The most predominant social media tool used is WhatsApp during acute events to get information by the citizen since one can express their emotions with a simple smiley icon. At the time of emergency, WhatsApp is being used as an official mode of communication by various authorities. Many WhatsApp users tend to believe what they receive and forward the same without verification.

\section{Background}

Viruses can be controlled by medicines but controlling rumours is a very difficult task. At this juncture of the corona event, rumour touches all the fields such as home remedies and precautionary methods, Quarantine and lockdown, hackers and strangers, the origin of coronavirus, measures taken by the government. This study focuses on the different types of 
Towards Excellence: An Indexed, Refereed \& Peer Reviewed Journal of Higher Education / R. Hepzibah Gnana Sinthiya \& Dr. Kishore Kulothungan / Page 113-125

rumours that spread during the outbreak of corona in WhatsApp and the impact of such rumours and the steps taken by the government to control the rumours.

\section{Review of literature}

Social media helps to improve the standard of rural people (Moeller, 2013). He strived to find whether social media platforms help in rural development. He found that various social media applications are used to meet the needs of the people. This study supports Bansal, but there is also a need to find how fast the rumours spread in social media in rural areas.

Gupta (2016) attempted to describe the connection between social media and rural India. The author found that "social media provides various facilities to communicate with the rural area people". With the help of mobile banking and recent technology, one can break the hindrance of communication, such as the differences in language, culture, etc. From this study, one can explore whether the lack of communication makes a significant difference in spreading rumours.

Roopavathi \& Kishore (2020) found that the motive behind the rumours is to get recognition in a group. Anbazhagi and Kishore (2020) found that news spead faster in digital era among groups.

According to Ganguly (2019) Seventy-eight percent of the respondents believe that the WhatsApp is safe and secure to keep their personal details and $87 \%$ of them trust that these messaging platforms have taken effective steps to control the spread of misinformation. The main objective of Shreya Ganguly was to explore why Whatsapp is India's most preferred social media app inspite of rumours and fake news. Based on the study of Ganguly, a study on WhatsApp and the steps taken by the government to reduce the spread of misinformation and rumours was investigated.

The find out the reason to spread fake news by the ordinary citizens was the motive behind a survey conducted by Santanu, Lucile and Sapna (2018). The data was collected from 80 participants over three countries (Nigeria, India, Kenya) and 16000 Twitter accounts and 3000 Facebook pages where analyzed. It is concluded that without verifying the news people spread the fake news with the belief that they were helping to spread the true story. People were also overconfident about their ability to spot the fake news. In all the three countries from which data collected explored that the distance of mainstream news outlets pushed people to spread fake news. There is also a need to find whether the literacy factor plays a vital role in spotting the fake news

Controlling the spread of rumours does not deal with the individual. people who are in different backgrounds such as actors, media organizations, government, civil society, and all other professionals need to come together to tackle the problem of spreading fake news. In fact, it is a social problem more than a technical problem. Verifying the flow of fake news, especially in the form of memes and images is difficult to identify its veracity. Hence, socio-political identity plays a key role in sharing the fake news. It is very difficult to control the spread of fake news since India is a secular and democratic country. Therefore, there is a need to control the spread of fake news through various effective measures (Santanu, Lucile and Sapna, 2018).

Maria Thomas (2018) bids to find the impact of fake news crisis in India. The study states that even though the Indian government has issued the Stern warning to Facebook-owned 
messaging services, which has limited the number of times a message can be forwarded, India's fake news crisis and the weaponization of social media with the only intensifier in the forthcoming election year. Accordingly, there is a need to find the consequences faced by the political party is due to the rumours and fake news during the general election 2019 in India.

According a news published by ET Bureau (Telecom News, 2018) the Indian home ministry insists on global internet and social media firms to appoint regional officers to curb the misuse of social media sites. All the social media platforms should co-operate together to overcome the misuse of social media, but the report says that WhatsApp did not give a proper response to the questions raised by the economic times. It also says that certain social media platforms like Facebook remove offensive contents regularly, if it creates any controversy to the community standards. They also meet with MHA (Ministry of Home Affairs) frequently, to update them on the contents that are banned by the Indian government. The spokesperson of social media players explained the government representatives about the control measures taken by them to ensure blocking of websites, removal of controversial content from the view of the public. But the question here is, how far the action taken by both the social media platforms and the government is effective in reducing the rumours.

Lisa Clark (2012) states that, from the rumour and hoaxes of social media, entrepreneurs can learn a lot nowadays and also the power of influence of networks by their users. When people hold a leadership position on the web they should be very conscious and careful while using social media. Social media is not a play game or a toy to be used for fun or unnecessarily. Only because of trust and belief, social media users open up a particular site in search of any information or advice. Hence, while sharing a post one should check enough number of times to make sure that the information is authenticated, otherwise, it tends to cheat their followers. Business people will always try experiments with social media and it should not cost their users. The leaders should understand that their followers are not testing rats to use them for their benefits only. Further, a study can focus on the aim to find the role of social media rumours in the business world.

Janet \& Jun (2018) conducted a research to find whether the public can differentiate the truth from disaster-related rumours. Ultimately, people depend on social media to know the current scenario when the disaster takes place. Disaster-related rumours make the decision making process critical and put both the resident and the emergency responders at a greater risk. This research concludes that people in society are not very good at identifying the rumours related to the disaster. One can further study the role of social media and the steps taken to demolish the rumours that spread during natural disasters.

A survey was conducted by Alzanin \& Azmi (2018) to deduct the rumors on social media. It states that, with the escalation of social media, it is very easy to access the information by all the users. Some states or regions have a great interest in deducting social media rumors but many lacks. Many rumor deduction systems are developed to eliminate information that leads to rumours when there is no authentic information regarding a particular subject matter and also the growth of social media is rapidly increasing, which is used even by the illiterate people for entertainment purposes. Further, by keeping this paper as a base, one can analyze the effectiveness of the rumour deduction system that is already been developed.

Non-profit driven social media platforms will be the best solution to overcome social media threats. Earning profits is the primary motive for these kinds of social media platforms. Once it affects the profits, the threats to social media might disappear. Even though both the 
social media and the internet are machine-based, government agencies have some hierarchical power in their jurisdiction to get favor from the social media authorities, which can be bypassed eventually with some technical knowledge (Kaynar, 2016).

UGC (User Generated Content) is a term that indicates the information, contents, and materials that is visible on blogs, websites, etc., which is generated by social media users. During social crises, the usage of social media changes rapidly in every aspect of its usage. The information and contents shared in the social media urge the people to initiate actions either positively or negatively, according to the understanding of users about the information shared. Proper understanding of the information that is being posted on social media websites helps to counter the rumors and reduces the information gap which leads to disruption and confusion among the public. Further, a study can be done to find whether the information gaps are filled by the rumors (Irenoa, 2014).

What's app has become very familiar not only to share contents, texts, images, chats, etc., but it has also created plenty of business opportunities for small entrepreneurs to reach the customers with its digital presence. Even though WhatsApp has many benefits, it has been widely used to spread fake news, over the years (Sushma, 2018). It is also mentioned that WhatsApp cannot dodge its responsibility when good technological inventions are misused by some culprits. Hence, to understand the safety problems and to reduce the rumors it is decided that, the WhatsApp research awards will fund independent research proposals, to see what the company can do about the spread of rumors. This study focused on which social media platforms spread more rumors.

Yadav (2020) manager at Godrej Agrovet expressed the egg and chicken sales were hit by the coronavirus rumour. He also mentioned that the consumption of chicken has dropped up to 50 percent, where the prices have come down to 70 percent as a result of coronavirus rumours. The company sells $6,00,000$ fresh and frozen chicken every week but the earnings of the company came down to 10 to 11 percentage after the attack of the corona. He said that the company Faces short-term challenge because of coronavirus scare which resulted in the drop of the conception of chicken in the country. Yadav also stated that it is not only the company that faces tremendous loss but also the farmers who own poultry is facing loss for the past 3 to 4 weeks.

According to Mega Mandavia (2020), various social media platforms are fighting against the rumours and have taken effective measures to control the spread of coronavirus rumours along with the ministry of health and family welfare and the World health organization. They have launched a prompt search for Indians, to give authorized information about the health issues when the netizens search about the virus. Google, YouTube, and Facebook also sent links regarding coronavirus to WHO. Most of the videos on social media have given correct precautionary measures but some give irrational methods that are not true. The contents posted with claims and conspiracy are removed by Facebook. When a person relies on social media information, it makes them fall sick or guides them to wrong treatment.

TikTok, A Chinese short video platform that is owned by Byte Dance, has taken efforts to stop the romours by releasing videos in 8 Indian languages for its users to educate them to verify the information they receive w with the official WHO links. Many other social media applications like Helo app, share chats, etc., have also taken effective measures to stop the social media rumours. 
Soutika Biswas (2020), claims the false information that spreads on social media might increase the infections when people tend to believe it. Sumaiya Shaikh, editor of fact-checking site Alt News Science says that the viral misinformation that spreads on WhatsApp regarding home remedies such as ginger, garlic, vitamin-c will prevent the spread of coronavirus. He also mentions that these kinds of rumours reinforce 'the big Pharma hoax' which is not encouraged by the pharmaceutical to treat the people. Other misinformation such as yoga, consuming cow urine, and dung, inhaling cannabis for the prevention of virus are also been spread widely. To stop such rumours government-appointed advisory committee of homeopathy drug and local indigenous medicine to prevent and manage the spread of infection. Moreover, the citizens who come across the information should be vigilant and check with the fact-checkers before adopting any remedial measures they come across. A study can be done to highlight the consequences faced by the public because of coronavirus hoaxes.

According to Jane (2020) The Rumours and hoaxes regarding coronavirus in WhatsApp over the globe during acute events create a greater impact in the society. The hoaxes regarding coronavirus create a panic situation among the public as it deals with health issues. Here is the list of rumours that are running around in WhatsApp regarding the precautionary measures, home remedies to gid rid of coronavirus, etc., They are:

$>$ The cities will go in full shutdown- (fig.1) a false text message mentioning that it is from various officials. The information was further clarified by the authorities to be false.

> Quarantine in UN-(fig.2) The misinformation that spreads about separation in WhatsApp

The national security council verified that those messages are false. (fig.3)

$>$ Colloidal silver, vitamins, teas, and essentials oils remedies for novel coronavirus- the US authorities cracked out that these treatments are not approved remedies for corona (fig 4).

$>$ Hackers using the situation to steal the credential pieces of information of the users by sending them links via WhatsApp and emails (fig 5)

$>$ A popular post states that drinking plenty of water produces acid in the stomach which kills the virus and also drinking warm water for every 15 minutes will prevent further infection. (fig 6)

This information passed as a text message, a picture message which turned as a meme (fig 7) for further false claim, and also in an audio message (audio link-1), which is said to be very bad advice according to various health experts.

$>$ Taking a deep breath of hot air from a hairdryer cures coronavirus - a video in youtube falsely stated that taking in of hot hair kills the viruses, which is viewed by half a million netizens. (fig.8) (audio link-2), Some officials also have repeated these false claims as it is published by a reliable source.

$>$ In Australia, (audio link-3), a fake audio clip was attributed to the member of parliament Chris Bowen who is also Australia's shadow minister of health. The official from the Bowen office mentioned that the audio clip is not true and they are not sure about its origin.

$>$ A screenshot that warns the people of new jersey, the UK, and France to not open the doors unnecessarily as strangers are roaming around the streets, which is said to be a fake message. (fig.9) 
Towards Excellence: An Indexed, Refereed \& Peer Reviewed Journal of Higher Education / R. Hepzibah Gnana Sinthiya \& Dr. Kishore Kulothungan / Page 113-125

$>$ During the starting days of the corona outbreak, the politically interested people intend to spread the conspiracy about the origin of coronavirus. Certain people said that it is from a lab in Wuhan and others without any base claimed that it was stolen from a lab in Canada. (fig.10) The research was done to find the origin of the virus, it showed that the virus evolved organically. The scientist concluded that the results show that "the analysis reveals that SARS-CoV-2 is not a constructed or purposefully manipulated virus". (fig.11)

$>$ There are no home testing kits for COVID-19-(fig.12) The US food and drug administration proclaimed that they did not approve any such testing kits for the virus.

$>500$ lions were realized in Russia to threaten the people to stay indoors. (fig 13) To create a fake "breaking news", the picture was created with a free to tool.

According to Radhakrishnan, 'Fighting the rumours is very tougher than fighting the virus' said Radhakrishnan, commissioner of revenue administrator, disaster management and mitigation (Times of India, 2020). WhatsApp and other social media networks are flooded with rumours more than viral infections. A voice message is passing around stating that the Covid 19 is a secret plan by the health department to reduce the population of the country. one more message is circulated mentioning that the government is going to shut down all the transportation and the shops in the cities. Both messages are not true. The state government has taken several effective measures to control the rumours and have also implemented strict laws against the rumours spreaders. Kolandaswamy, director of public health said that the punishment will be very severe which includes 7 years of Jail. The deputy director of health service Ramesh Kumar also stated that the rumour spreaders will be punished under the Tamil Nadu public health act 1939 and section 54 (punishment for false warning) of the disaster management act 2005. A so-called self-proclaimed medical practitioner "Healer" Basker was arrested as a case was filed against him by the public health department. He released an audio clip telling that the corona positive patients will be isolated and eliminates later which is false news. Selvam whose of 40 years, in Madurai, arrested for spreading misinformation that 47 infected patients were kept quarantined in an apartment near Othakadai in Madurai. This created panic among the residents and they started to protest without verifying the information. Hence, He has been arrested under the IT act and disaster management act 2005 and kept remanded in judicial custody.

\section{Objective of the study}

To classify the types of rumours in WhatsApp that occurs during an acute event Covid 19

To analyze the impact of such rumours

$>$ To highlight the measures taken by the Tamilnadu state (India) government to control rumours

$>$ To suggest methods to identify and deduct rumours

\section{Research methodology}

The rumours that circulated during the acute event Covid-19 were collected as the primary data from various sources. This study classifies rumours by constructing a model. Coding and labeling were used to group the features of the event and to classify the rumors. The impact of the rumours was analyzed through a statistical tool called ANOVA. The primary 
Towards Excellence: An Indexed, Refereed \& Peer Reviewed Journal of Higher Education / R. Hepzibah Gnana Sinthiya \& Dr. Kishore Kulothungan / Page 113-125

data was collected from 7 WhatsApp groups in Vellore city from $1^{\text {st }}$ March to $30^{\text {th }}$ march. The first group consists of 26 members, where 19 rumours were taken. The second group consists of 110 members from which 30 false messages were collected. The third group is about 54 people, 16 misinformations were taken. The fourth group holds 69 members, where 20 rumours were taken. 5 false pieces of information were collected from the fifth group which consists of 22 members. From the sixth group, 12 rumours were collected, which have 32 participants. And finally, from the seventh group, 5 rumours were taken which holds 10 members. The conclusion was given according to the results derived.

\section{Rumour classification model}

As WhatsApp has become the basic mode of communication for every netizen, they tend to share all the feelings and emotions through it. Due to the unexpected acute event in society, the public becomes panic which creates changes in their behavior. Mostly, behavioral changes are determined by the words expressed by a person, that too when communication takes place through WhatsApp chats the sender and the receiver do not have face contact with each other which paves more possibility of misunderstanding. Hence, it automatically leads to rumours.

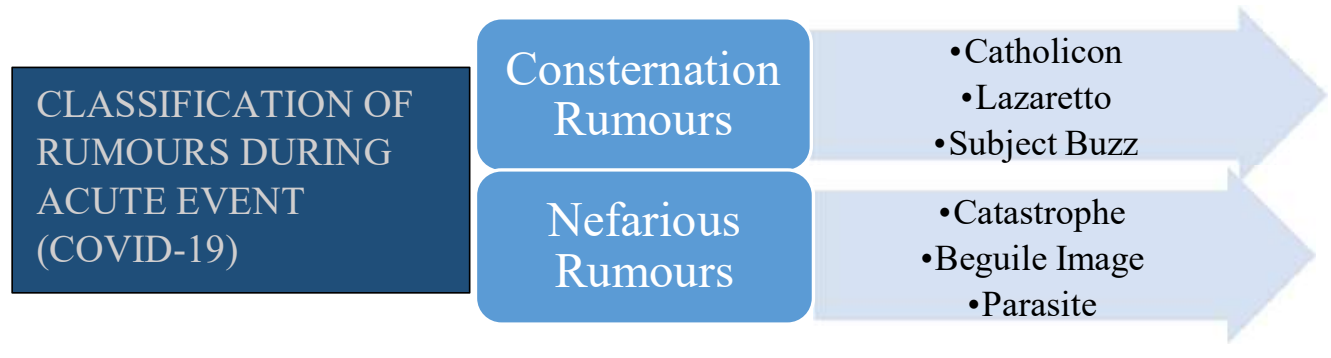

Diagram-1.1

\begin{tabular}{|c|c|c|}
\hline \multicolumn{2}{|r|}{ Table 1.1 (Descriptive table) } & \\
\hline \multicolumn{2}{|c|}{ TYPES OF RUMOURS } & $\begin{array}{l}\text { No. Of Times } \\
\text { Occurred }\end{array}$ \\
\hline \multirow{3}{*}{$\begin{array}{l}\text { Consternation } \\
\text { Rumours }\end{array}$} & Catholicon (natural remedies) & 29 \\
\hline & Lazaretto (quarantine) & 12 \\
\hline & Subject Buzz (direct subject matter-covid19) & 23 \\
\hline \multirow{3}{*}{ Nefarious Rumours } & Parasite rumours (third person) & 9 \\
\hline & Catastrophe (business hit) & 14 \\
\hline & Beguile Image (fake images) & 20 \\
\hline
\end{tabular}


Towards Excellence: An Indexed, Refereed \& Peer Reviewed Journal of Higher Education / R. Hepzibah Gnana Sinthiya \& Dr. Kishore Kulothungan / Page 113-125

This study classifies the rumours that occurred during the Covid 19 acute event (fig 1.1). From the collected literature, the study classifies the rumours basically into two types. 1 . Consternation rumours (rumours that occur due to panic) 2. Nefarious rumours ( rumours arises due to social villain). Further, the consternation rumours are classified as catholicon (rumours that relate to natural healing process), lazaretto (rumours relating to shutdown) and subject buzz (direct subject-matter rumours). The nefarious rumours are divided as parasite (thirdperson), catastrophe (business hits), and beguile image (fake pictures). The impact of these rumours are analysed with the help of primary data (by collecting the rumours from 7 groups of a netizens WhatsApp number). Statistical tool ANOVA is used to test the significance.

\section{Analysis}

Hypothesis - at 0.005 Significance level

$\mathbf{H}_{\mathbf{0}}$ - There is no significant difference in the impact rumors between the groups

$\mathbf{H}_{1}$ - There is a significant difference in the impact of rumors between the groups

ANOVA Table 1.2

\begin{tabular}{|l|l|l|l|l|l|l|}
\hline Source of variance & SS & df & MS & F & p-value & F crit \\
\hline $\begin{array}{l}\text { Between the } \\
\text { groups }\end{array}$ & 11583.36 & 7 & 1654.765306 & 10.87341383 & $\begin{array}{l}3.98 \mathrm{E}- \\
08\end{array}$ & 2.207436 \\
\hline Within groups & 7304.857 & 48 & 152.1845238 & & & \\
\hline Total & 18888.21 & 55 & & & & \\
\hline
\end{tabular}

As Per the ANOVA Table, the P-value is greater than the significance level i.e. 3.98. Hence, the alternative hypothesis is rejected and the null hypothesis is accepted.

\section{Result and Discussion}

Based on the analysis, the result concludes that all the rumours have an equal impact on the society between the groups. The descriptive table shows that the Catholicon rumours and Subject Buzz rumors occur more number of times comparatively. The F value states that there is a 10.87 times difference in the occurrence of rumors between the groups. Therefore both the Consternation rumours and the nefarious rumours have an equal impact on society. Mostly nefarious rumours are created for entertainment purposes which creates both merits and demerits in the society. The analysis also reveals that people are health conscious and much interested in home remedies.

\section{Suggestions}

It is very important to find and avoid fake news. It should be noted that the authenticity of the image and news should be verified before forwarding the news or message. Messages which carries to forward and share should be dealt with care and responsibility. The option of message forwarding facilities should be locked. 


\section{Conclusion}

This study concludes by stating that all the rumors have an equal impact on society. As people are more concerned about their health and they tend to get more panic when they receive any kind of information. The Tamil Nadu state (India) government has taken various measures to control the spread of rumours such as, publishing awareness videos, sending authorized links to the social networks, providing official corona helpdesk contact number and also by implementing strict laws like sentencing under the Tamil Nadu public health act 1939 and section 54 (punishment for false warning) of the disaster management act 2005 against the social villains. The WhatsApp company has also taken various measures like limiting the forwards at a time, providing WhatsApp chatbot, WhatsApp tipline number, etc., However, unless and until every individual step forward to eradicate the rumour, it is impossible to stop the spread of rumours. People who come across such information should inculcate the habit of verifying before forwarding to others and should also follow the suggestions given in this study. Further, one can make coding on classified rumours and develop a module using the algorithm to curb the spread of fake news in WhatsApp completely. 
Towards Excellence: An Indexed, Refereed \& Peer Reviewed Journal of Higher Education / R.

\section{Hepzibah Gnana Sinthiya \& Dr. Kishore Kulothungan / Page 113-125}

ANNEXURE

\section{Types of Rumours based on Groups (coding)}

\begin{tabular}{|l|l|l|l|l|l|l|l|}
\hline $\begin{array}{l}\text { Group } \\
\text { s }\end{array}$ & Participants & $\begin{array}{l}\text { Catholico } \\
\text { n (natural } \\
\text { remedies) }\end{array}$ & $\begin{array}{l}\text { Lazaretto } \\
\text { (quarantin } \\
\text { e) }\end{array}$ & $\begin{array}{l}\text { Subject } \\
\text { buzz } \\
\text { (direct } \\
\text { subject } \\
\text { matter- } \\
\text { covid19) }\end{array}$ & $\begin{array}{l}\text { Parasite } \\
\text { rumours } \\
\text { (third } \\
\text { person) }\end{array}$ & $\begin{array}{l}\text { Catastroph } \\
\text { e (business } \\
\text { hit) }\end{array}$ & $\begin{array}{l}\text { Beguile } \\
\text { image } \\
\text { (fake } \\
\text { images) }\end{array}$ \\
\hline 1 & 26 & 4 & 2 & 5 & 1 & 3 & 4 \\
\hline 2 & 110 & 10 & 3 & 4 & 2 & 5 & 6 \\
\hline 3 & 54 & 3 & 2 & 4 & 1 & 3 & 3 \\
\hline 4 & 69 & 6 & 3 & 4 & 2 & 2 & 3 \\
\hline 5 & 22 & 2 & 0 & 1 & 1 & 0 & 1 \\
\hline 6 & 32 & 4 & 1 & 3 & 1 & 1 & 2 \\
\hline 7 & 10 & 0 & 1 & 2 & 1 & 0 & 1 \\
\hline
\end{tabular}

Table 1.3

Figures, Audio links:

\section{Figures :}

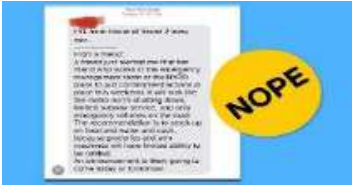

Fig.1

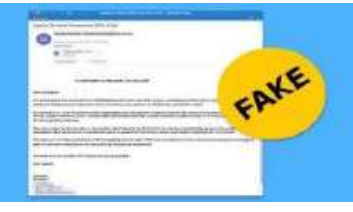

Fig.5

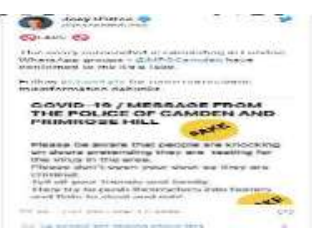

Fig.9

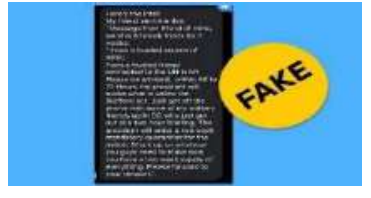

Fig.2

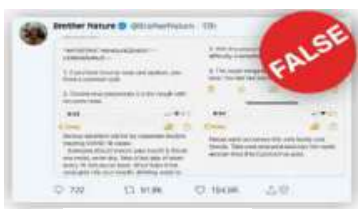

Fig.6

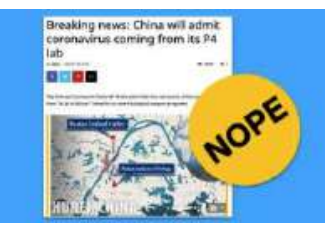

Fig.10

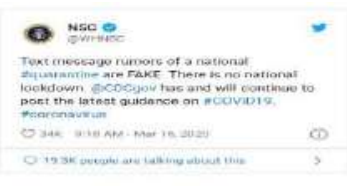

Fig.3

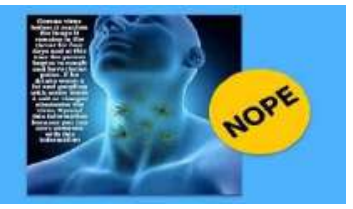

Fig.7

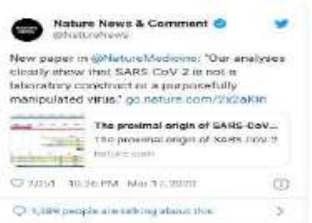

Fig.11

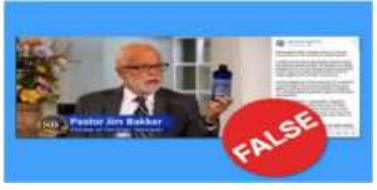

Fig.4

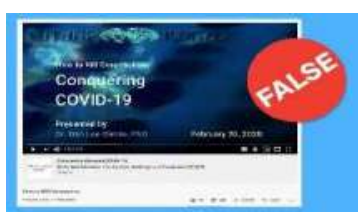

Fig.8

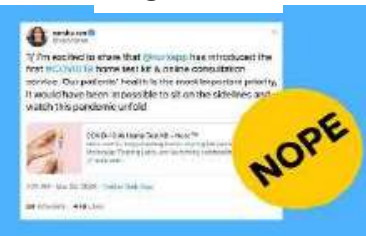

Fig.12

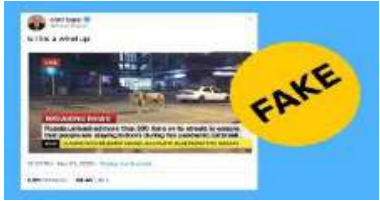


Towards Excellence: An Indexed, Refereed \& Peer Reviewed Journal of Higher Education / R. Hepzibah Gnana Sinthiya \& Dr. Kishore Kulothungan / Page 113-125

\section{Audio links:}

Audio link 1- https://soundcloud.com/jane-lytvynenko/fake-covid-19-audio3

Audio link 2- https://twitter.com/BillyCorben/status/1241740081343447040

Audio link 3- https://soundcloud.com/jane-lytvynenko/fake-covid-10-audio2 
Towards Excellence: An Indexed, Refereed \& Peer Reviewed Journal of Higher Education / R. Hepzibah Gnana Sinthiya \& Dr. Kishore Kulothungan / Page 113-125

\section{References}

Alzanin, S. M., \& Azmi, A. M. (2018). Detecting rumors in social media: A survey. Procedia Computer Science, 142(January), 294-300. https://doi.org/10.1016/j.procs.2018.10.495

Anbazhagi \& Kishore Kulothungan (2020). Digital Entrepreneurship- Studies In Indian Place Names/ISSN: 2394-3114 Vol-40-Issue-18-February -2020

Chennai News (2020) Besides virus, Tamil Nadu government battles fake news | Chennai News - Times of India. (n.d.). Retrieved March 26, 2020, from https://timesofindia.indiatimes.com/city/chennai/besides-virus-govt-battles-fakenews/articleshow/74700454.cms

ET Bureau (2018) Govt tells Google, FB to monitor rumours, alert authorities, Telecom News, ET Telecom. (n.d.). Retrieved March 18, 2020, from https://telecom.economictimes.indiatimes.com/news/govt-tells-google-fb-to-monitorrumours-alert-authorities/66372176

Ganguly (2019), "Despite Fake News and Rumours, WhatsApp Is Most Preferred In India. (n.d.). Retrieved March 17, 2020, from https://inc42.com/features/despite-fake-newswhatsapp-indias-most-preferred-social-media-app/

Gupta, S. (2016). A STUDY ON: IMPACT OF SOCIAL MEDIA IN RURAL Abstract: Introduction : References : 66-68.

Irenoa, K. O. (2014). Understanding the Informational and Normativee Influences of Rumour Diffucion Via Social Media on Conflicts Escalation. Libs 805 - Seminar I, 1-19.

Jane (2020) Coronavirus Rumors: Running List Of Fake News, Hoaxes, Disinformation. (n.d.). Retrieved March 25, 2020, from https://www.buzzfeednews.com/article/janelytvynenko/coronavirus-fake-newsdisinformation-rumors-hoaxes

Janet \& Jun (2018) How rumors spread on social media during weather disasters NSF National Science Foundation. (n.d.). Retrieved March 18, 2020, from https://www.nsf.gov/discoveries/disc_summ.jsp?cntn_id=296519\&WT.mc_id=USNS F_1

Kaynar, B. (2016). Rumor in Social Media : Role of Affect During Social Movements İstanbul Şehir University September 2016.

Lisa Clark (2012) Social Media Rumors and Hoaxes, Social Media Sun. (n.d.). Retrieved March 18, 2020, from http://socialmediasun.com/social-media-rumors/

Mangal Limbaji Fartade, S. K. G. (2020). Studies in Indian Place Names. UGC Care Journal, 40(56), 41-47.

Maria Thomas (2018) BBC study shows how Indians spread fake news on WhatsApp Quartz India. (n.d.). Retrieved March 18, 2020, from https://qz.com/india/1459818/bbc-study-shows-how-indians-spread-fake-news-onwhatsapp/ 
Towards Excellence: An Indexed, Refereed \& Peer Reviewed Journal of Higher Education / R. Hepzibah Gnana Sinthiya \& Dr. Kishore Kulothungan / Page 113-125

Mega Mandavia (2020) Tech platforms fight to control coronavirus rumours - The Economic Times. (n.d.). Retrieved March 20, 2020, from https://economictimes.indiatimes.com/tech/internet/tech-platforms-fight-to-controlcoronavirus-rumours/articleshow/74050624.cms?from $=\mathrm{mdr}$

Moeller, R. R. (2013). Impact of Social Media Computing. Executive's Guide to IT Governance, 355-370. https://doi.org/10.1002/9781118540176.ch21

Roopavathi \& Kishore (2020). Motivational factors of Employee Retention and Engagement in Organization, 1080-1085. https://doi.org/10.12733. VII2.535569.11713

Santanu, Lucile and Sapna (2018) DUTY, IDENTITY, CREDIBILITY Fake news and the ordinary citizen in India. (n.d.). BBC, UK

Santanu, Lucile and Sapna (2018) Nationalism a driving force behind fake news in India, research shows - BBC News. (n.d.). Retrieved March 17, 2020, from https://www.bbc.com/news/world-46146877

Soutika Biswas (2020) Coronavirus: Is India prepared for an outbreak? - BBC News. (n.d.). Retrieved March 20, 2020, from https://www.bbc.com/news/world-asia-india51747932

Sushma (2018) After a spate of lynchings, India blames WhatsApp for the spread of fake news - Quartz India. (n.d.). Retrieved March 18, 2020, from https://qz.com/india/1320859/after-a-spate-of-lynchings-india-blames-whatsapp-forthe-spread-of-fake-news/

Wang, Y., Ma, F., Jin, Z., Yuan, Y., Xun, G., Jha, K., Su, L., \& Gao, J. (2018). EANN: Event adversarial neural networks for multi-modal fake news detection. Proceedings of the ACM SIGKDD International Conference on Knowledge Discovery and Data Mining, 849-857. https://doi.org/10.1145/3219819.3219903

Yadav (2020) Coronavirus rumours hit sales of egg, chicken - The Economic Times. (n.d.). Retrieved March 20, 2020, from https://economictimes.indiatimes.com/industry/consproducts/food/coronavirus-rumour-hits-sales-of-egg-

chicken/articleshow/74362789.cms?from $=\mathrm{mdr}$

\section{R. Hepzibah Gnana Sinthiya \\ Research Scholar \\ Post Graduate \& Research Department of Commerce \\ Voorhees College \\ Vellore, Tamilnadu, India}

Email: hepzibha@voorheescollege.edu.in,Phone:+919489577107

\&

Dr. Kishore Kulothungan

Research Supervisor

Post Graduate \& Research Department of Commerce

Voorhees College

Vellore, Tamilnadu, India

Email: kishore@voorheescollege.edu.in, Phone: $\mathbf{+ 9 1 9 4 8 8 8 5 6 8 7 8}$ 